\title{
メッシュレス法を用いた振動解析
}

\section{Vibration Analysis Using a Meshless Method}

\author{
小川大介 (名大院) 正 神谷恵輔 (名大) 正 安田仁彦 (名大)
}

\author{
Daisuke OGAWA, Nagoya University, Furo-cho, Chikusa-ku, Nagoya \\ Keisuke KAMIYA, Nagoya University \\ Kimihiko YASUDA, Nagoya University
}

Key Words: Meshless method, Vibration analysis, Moving least square method

\section{1.まえがき}

機械, 構造物等の解析手法として有限要素法 (FEM)が 広く用いられている. FEM は問題とする領域のメッシュ 分割に多大な時間が費やされることが問題点となってい る.このため,メッシュ分割をせずに解析を行うメッシュ レス法に関する研究が, 近年盛んに行われている。しか し，メッシュレス法を動的問題へ応用している研究は比 較的少ない. 特に, 変位加振や, 境界条件が変位の関係 式で与えられる場合の解析手法についての研究は見あた らない，本研究では，これらの問題に対する手法を提案 する.

\section{2. 基礎理論}

$2 \cdot 1$ 移動最小二乗近似 本研究では移動最小二乗近 似 (MLSA) に基づくメッシュレス法 [1]を取り上げる. 説 明の簡単のため, 一次元問題を考える. 問題例としては, 棒の軸振動やねじり振動, はりの曲げ振動などがある. 位 置を表す座標を $x$, 時刻を $t$ とし, 対象物の変位を $u(x, t)$ とする.

位置 $x=x_{i}(i=1,2, \cdots, N)$ に節点を配置し，各節点に おいて節点值 $\hat{u}_{i}(t)$ を導入する. 移動最小二乗法の考え方 に従って, 変位 $u$ を

$$
\begin{aligned}
u(x, t) & =a_{1}(x, t)+a_{2}(x, t) x+a_{3}(x, t) x^{2}+\cdots \\
& =a^{T}(x, t) p(x)
\end{aligned}
$$

の形におく.ここに $a_{j}(x, t)$ は $x, t$ の未知関数である. 節 点值 $\hat{u}_{i}(t)$ を用いて $a_{j}(x, t)$ を表すことを考える. このため

$$
J(\boldsymbol{a}(x, t))=\sum_{i=1}^{N} w_{i}(x)\left\{\boldsymbol{a}^{T}(x, t) p\left(x_{i}\right)-\hat{u}_{i}(t)\right\}^{2}
$$

で定義される評価関数 $J$ を導入する．ここに $w_{i}(x)$ は，節 点位置 $x_{i}$ を中心にある範囲で非負であり，その範囲外で は零となる適当な重み関数である. 上式で与えられる $J$ を最小にするように $a_{j}(x, t)$ を定める. 定めた $a_{j}(x, t)$ を 式(1)へ代入し, 整理すれば

$$
u(x, t)=\phi^{T}(x) \hat{u}(t)
$$

の形の式を得る.ここに $\hat{\boldsymbol{u}}(t)$ は節点值 $\hat{u}_{i}(t)$ を並べてでき るべクトルである. 以上の手順で定めた $u(x, t)$ は一般に,

$$
u\left(x_{i}, t\right) \neq \hat{u}_{i}(t)
$$

であることに注意されたい.

上記では節点值として変位 $u$ のみを考えたが，これに 加えて $u$ の導関数の值を節点值とすることもできる. こ の方法は一般化最小二乗近似 (GMLSA) と呼ばれる [2].
2.2 選点的境界条件の導入 式 (3) を，考えている 問題の運動方程式へ代入し，ガラーキン法を適用すれば

$$
M \ddot{\hat{u}}+K \hat{u}=f
$$

の形の式を得る. 上式を与えられた境界条件のもとに解け ば, 解が求められる. しかし, MLSA あるいは GMLSA で は, 式(4) からわかるように, 位置 $x_{i}$ における変位 $u\left(x_{i}, t\right)$ は節点值 $\hat{u}_{i}(t)$ と一致しないため, FEMのようには境界条 件や拘束条件を課すことができない.

境界条件や拘束条件を課すための方法としていくつか の方法が提案されている. 動的な問題に対して, Ouatuati らは特異值分解を利用することを提案している [3]. しか し, 変位加振による強制振動問題や, 境界条件が変位の 関係式で与えられる場合には適用できない. そこで，こ れらの場合にも適用できる方法を以下に提案する.

境界条件を含めた拘束条件を選点的に位置 $x_{n}$ で満た すことを考える．このとき，拘束条件は

$$
\sum_{n} c_{m n} B_{m n} u\left(x_{n}, t\right)=\tilde{q}_{m}(t), m=1,2, \cdots, s
$$

の形に書ける. ここに $c_{m n}$ は拘束条件で定まる定数, $B_{m n}$ は, 例えば変位拘束で $B_{m n}=1, x$ 方向の角度拘束で $B_{m n}=$ $\partial / \partial x$ となる演算子である. また $\tilde{q}_{m}(t)$ は変位等の指定值 である. 式 (3)を式 (6)に代入すれば,

$$
C \hat{u}(t)=\tilde{q}(t)
$$

の形の式を得る. 行列 $\boldsymbol{C}$ は特異值分解により,

$$
C=\left[\begin{array}{ll}
U_{1} & U_{2}
\end{array}\right]\left[\begin{array}{ll}
\Delta & 0 \\
0 & 0
\end{array}\right]\left[\begin{array}{l}
V_{1}^{T} \\
V_{2}^{T}
\end{array}\right]
$$

と書ける. 上式に現れる部分行列を用いて, 式

$$
\hat{\boldsymbol{u}}(t)=V_{2} \overline{\boldsymbol{u}}(t)+V_{1} \Delta^{-1} U_{1}^{T} \tilde{\boldsymbol{q}}(t)
$$

により末知量を $\hat{\boldsymbol{u}}(t)$ から $\overline{\boldsymbol{u}}(t)$ へ変換する. 上式で与えら れる $\overline{\boldsymbol{u}}(t)$ は拘束条件 $(7)$ を満足する.

式 (9) で与えられる $\hat{u}(t)$ を式(5)へ代入し, 左から $V_{2}^{T}$ を掛ければ

$$
\overline{\boldsymbol{M}} \ddot{\ddot{u}}+\overline{\boldsymbol{K}} \overline{\boldsymbol{u}}=\overline{\boldsymbol{f}}
$$

を得る. 上式を解いて $\overline{\boldsymbol{u}}(t)$ を求め, 式 (9), 式(3)へと順 次代入すれば変位を求めることができる。 


\section{3. 解析例}

3.1 変位加振による強制振動問題 図 1 に示す密度 $\rho$, 断面積 $A$, 曲げ剛性 $E I$ の一様な片持ちはりで自由端 に変位 $u=u_{0} \cos \omega t$, 傾き角 $\theta=0$ が与えられる場合を考 える.ここでは, 変位のみを末知量とする場合 (MLSA) と, 変位と傾き角を末知量とする場合 (GMLSA) の解析 を行った。

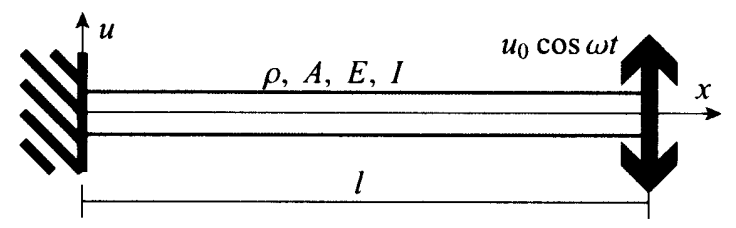

Fig. 1 Cantilever subjected to displacement excitation

MLSA と GMLSA のいずれも自由度数が 12 となるよ うにした. $u_{0}=1$ として, $\omega=50 \sqrt{E I / \rho A} / l^{2}$ での振幅分 布と $x=l / 3$ での共振曲線を図 2 に示す. 境界条件はどち らの場合も指定通りになっていることがわかる. MLSA と GMLSA の比較では, 同じ自由度数でも角度を自由度 として導人した場合の方が良い精度となった。
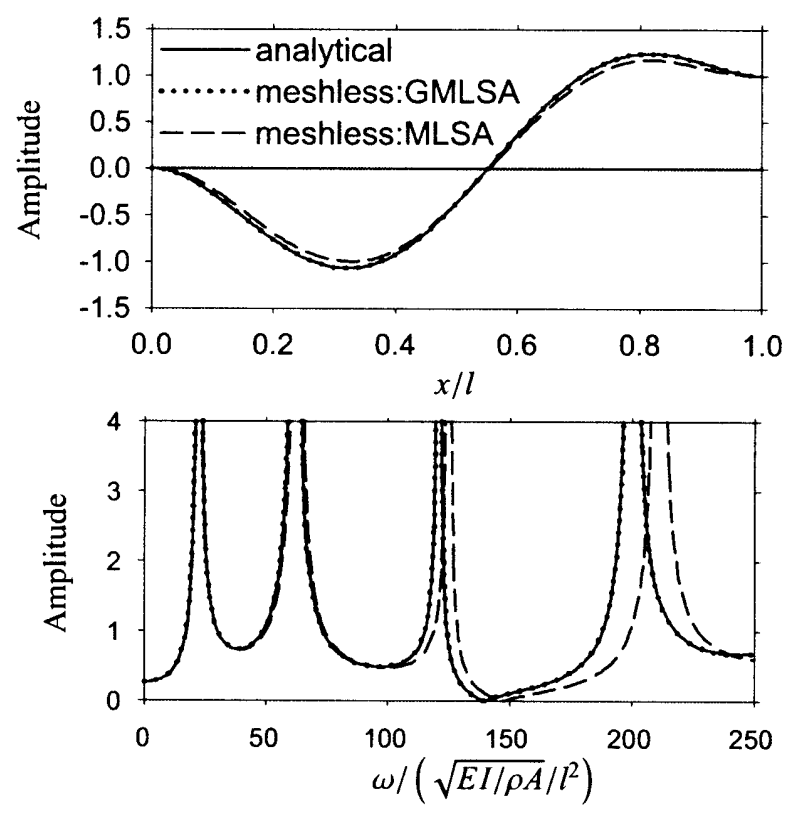

Fig. 2 Amplitude distribution and frequency response

3.2 拘束条件が変位の関係式で与えられる場合 図 3 に示す材料特性の異なる 2 つのはりが接合している場 合を考える. 以下では左右のはりをそれぞれ，はり $\mathrm{A}$, は り $\mathrm{B}$ と記し，それぞれのはりの物理量は, 添え字 $A, B$ を つけて区別する.ここでははり $\mathrm{A}$ とはり $\mathrm{B}$ を別々にメッ シュレス法で定式化し，接合部で変位と傾きが連続であ るという条件で全系の支配方程式を定めることを考える.

全系の末知量を $\hat{\boldsymbol{u}}=\left\{\begin{array}{ll}\hat{\boldsymbol{u}}_{A}^{T} & \hat{\boldsymbol{u}}_{B}^{T}\end{array}\right\}^{T}$ とすれば，いま考えて る問題の拘束条件は

$$
\left[\begin{array}{cccccc}
\phi_{A}(0) & \phi_{A}^{\prime}(0) & \phi_{A}\left(l_{A}\right) & \phi_{A}^{\prime}\left(l_{A}\right) & 0 & 0 \\
0 & 0 & -\phi_{B}(0) & -\phi_{B}^{\prime}(0) & \phi_{B}\left(l_{B}\right) & \phi_{B}^{\prime}\left(l_{B}\right)
\end{array}\right]^{T} \hat{\boldsymbol{u}}=\mathbf{0}
$$

と書ける. ここに肩のダッシュは $x$ に関する微分を表す.

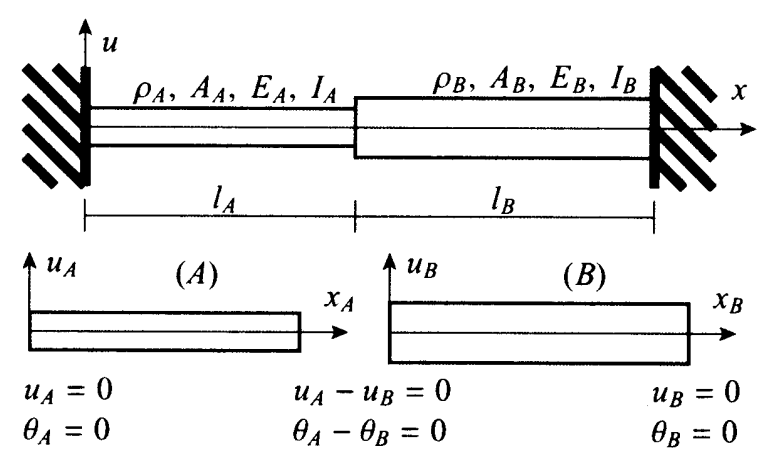

Fig. 3 Joined beam

ここでも MLSA と GMLSA を用いた場合の解析を行っ た. 両者ともに, 全自由度数が 16 となるようにした. ま た, $\rho_{B} A_{B} / \rho_{A} A_{A}=E_{B} I_{B} / E_{A} I_{A}=2$ とした. 求めた固有振 動数を表 1 に示す.この表には比較のため, 分割数を 30 とした場合の FEM で解析した結果をあわせて示してあ る.この場合でも，GMLSA を用いた場合の方が精度の 良い結果が得られた。

Table 1 Natural frequencies

\begin{tabular}{|c||c|c|c|c|c|}
\hline \multicolumn{1}{|c||}{} & \multicolumn{5}{c|}{$\omega /\left(\sqrt{E_{A} I_{A} / \rho_{A} A_{A}} / l_{A}^{2}\right)$} \\
\hline mode & 1 & 2 & 3 & 4 & 5 \\
\hline \hline FEM & 5.463 & 15.650 & 29.903 & 50.382 & 74.132 \\
GMLSA & 5.463 & 15.650 & 29.904 & 50.386 & 74.173 \\
MLSA & 5.478 & 15.849 & 30.431 & 52.316 & 77.402 \\
\hline
\end{tabular}

紙面の都合上, 本論文中では示していないが, 境界条 件や自由度数を変え, GMLSA と MLSA を用いた場合を 比較した，単純支持のように変位のみの拘束の場合は，両 者の違いは小さいが，固定端のように傾き角まで拘束す

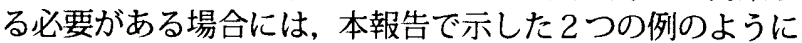
GMLSA を用いた場合の方が精度の良い結果を得られた.

\section{4. まとめ}

本報告ではメッシュレス法を用いて, 強制変位応答の 解析や, 拘束条件が未知量の関係式で与えられる場合の 解析手法を提案した. 提案した方法の有効性を数值例に よって示した. また MLSA と GMLSA を用いた場合の解 析精度の比較を行った。その結果, 提案した手法で角度 拘束を扱う場合には GMLSA を用いることで良好な結果 が得られることがわかった.

\section{文献}

(1) T. Belytschko, Y. Lu and L. Gu "Int. J. Numer. Meth. Engng.", 37, (1994), pp.229-256

(2) S. Atluri, H. Kim and J. Cho, "Comput. Mech.", 24, (1999), pp.334-347

(3) A. Ouatouati and D. Johnson, "Int. J. Numer. Meth. Engng.", 46, (1999), pp.1-27 